\section{PHYSICOCHEMICAL AND SENSORY CHARACTERISTIC OF STARFRUIT-RED GUAVA FRUIT LEATHER AS AFFECTED BY THE ADDITION OF ARABIC GUM}

\author{
Kharimatul Fachriah, Rahmawati Rahmawati*
}

Food Technology Program, Sahid University, Jl Prof. Dr. Supomo Nomor 84 Jakarta Selatan 12870 Indonesia

\author{
Article history \\ Received \\ 9 March 2021 \\ Received in revised form \\ 4 October 2021 \\ Accepted \\ 7 November 2021 \\ Published Online \\ 20 December 2021
}

*Corresponding author rahmafarasara@usahid.ac.id

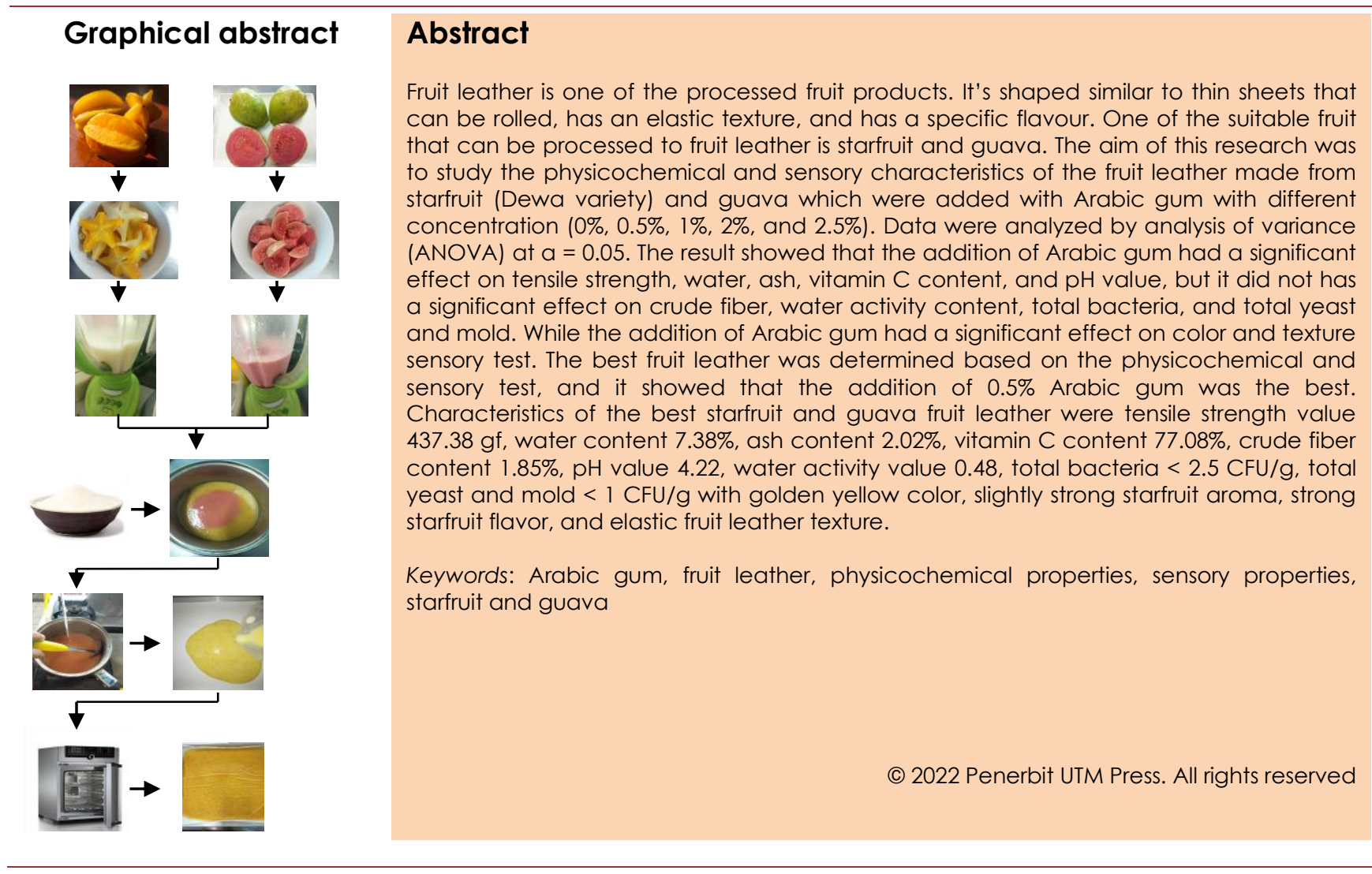

\subsection{INTRODUCTION}

Fruit leather is a fruit preserved product that is growing rapidly in various countries in the world [1] which can be consumed as candy or snacks [2]. Fruit leather is made from drying fruit puree to form a thin sheet that can be rolled with a thickness of 2 - $3 \mathrm{~mm}$, contains 10-20\% water, has a plastic texture, and has a specific consistency and flavor according to the type of fruits used [1].

In Indonesia, fruit leather has not widely known, but several studies have been conducted on processed fruit leather from various kinds of fruit, such as apple fruit leather [2], red guava fruit leather [3], papaya fruit leather [4], and others. Therefore, the Dewa starfruit fruit leather will be made, due to it is one of the best starfruit varieties in Indonesia and the world, which has become an icon of Depok city and is a local resource for the city of Depok [5]. There are 3 quality grades of (Dewa) starfruit, namely grade A, B, and C. They have similar taste and aroma. However, the size of grade $C$ is quite small ( $150 \mathrm{~g} /$ fruit) and out of the consumer preferences as fresh fruit. This situation needs to be solved, since the grade $C$ starfruit is processed into a limited local product, such as 
juice and dodol. In order to improve the quality of the produced fruit leather, it is formulated with red guava, which is also grows a lot in the city of Depok. Red guava is rich in vitamin C $164.69 \mathrm{mg} /$ $100 \mathrm{~g}$ of material) [6], has a pectin content of $4.1 \%$ $[7 ; 8]$. In comparison, starfruit has a pectin content of $0.56 \%$ [9] which is lower than red guava. To produced better quality fruit leather, hydrocolloids are needed to improve gel formation. One of the hydrocolloids that is widely used is Arabic gum. The application of Arabic gum improve the flexibility of the fruit leather, more than other stabilizers, such as maltodextrin, pectin, and CMC. Arabic gum also well known as the best hydrocolloid to maintain the quality of the fruit leather [10]. Based on these findings, the role of Arabic gum as a gelling agent in fruit leather production was observed.

\subsection{METHODOLOGY}

The process of starfruit (var. Dewa) and red guava fruit leather refers to [1] and [11] which consists of making puree and making fruit leather.

\subsection{Producing Starfruit Puree}

The starfruit used was a mix maturiry type of starfruits, i.e. ripe and half-ripe starfruit with a ratio of 2:1. The starfruit was washed by clean water and then blanched using the boiling method at $80^{\circ} \mathrm{C}$ for 15 minutes. The blanched starfruits were cut into small pieces with size of $\pm 2 \times 2 \mathrm{~cm}$, then crushed in a Turbo blender with a speed of 1 for 2 minutes (modification [1] and [11]).

\subsection{Producing Red Guava Puree}

The red guava fruits used were the mix of ripe and half-ripe red guava with a ratio of 2:1. Furthermore, the red guava fruits were washed by clean water and then blanched using the boiling method at $80^{\circ} \mathrm{C}$ for 15 minutes. The blanched red guava fruits were cut into small pieces with a size of $\pm 2 \times 2 \mathrm{~cm}$, then crushed with a Turbo blender with a speed of 1 for 2 minutes with the ratio of fruit and water 1:1. The puree of red guava was then filtered.

\subsection{Producing Fruit Leather}

Starfruit and red guava purees were mixed according to the designed formulation. In this study, five formulas were developed. Basically, each formula contain similar components, i.e. $83 \%$ starfruit puree, 9\% red guava puree, $8 \%$ sorbitol, and $0.05 \%$ citric acid. Arabic gum was applied to the formulas in various level, namely $0 \%, 0.5 \%, 1 \%$, $2 \%$, and $2.5 \%$ (Based on the previous study). Then the mixture was stirred manually until all the ingredients were mixed and heated at $70^{\circ} \mathrm{C}$ for 2 minutes. Cooked mixture $(400 \mathrm{ml})$ was then poured into an alumunium pan $(29.5 \mathrm{~cm} \times 20.5 \mathrm{~cm} \times 1 \mathrm{~cm})$ which has been coated with baking paper. Then, put it in the cabinet dryer, then dried it at $50^{\circ} \mathrm{C}$ for 24 hours. The flow chart of the fruit leather processing is drawn in Figure 1.

\subsection{Fruit Leather Analysis}

The quality of starfruit-red guava fruit leather was determined based on physical, chemical, microbiological, and sensory properties. The physical property was represented by tensile strength values [12]. The chemical properties being analyzed included water content [13], ash content [14], vitamin C content [13], crude fiber content [15], pH value [15], and water activity value [16]. The microbiological properties being analyzed included total bacteria [17] and total yeast and mold [18], while the sensory properties included the hedonic test [19] and hedonic quality test [19] for the parameters of color, aroma, flavor, and texture.

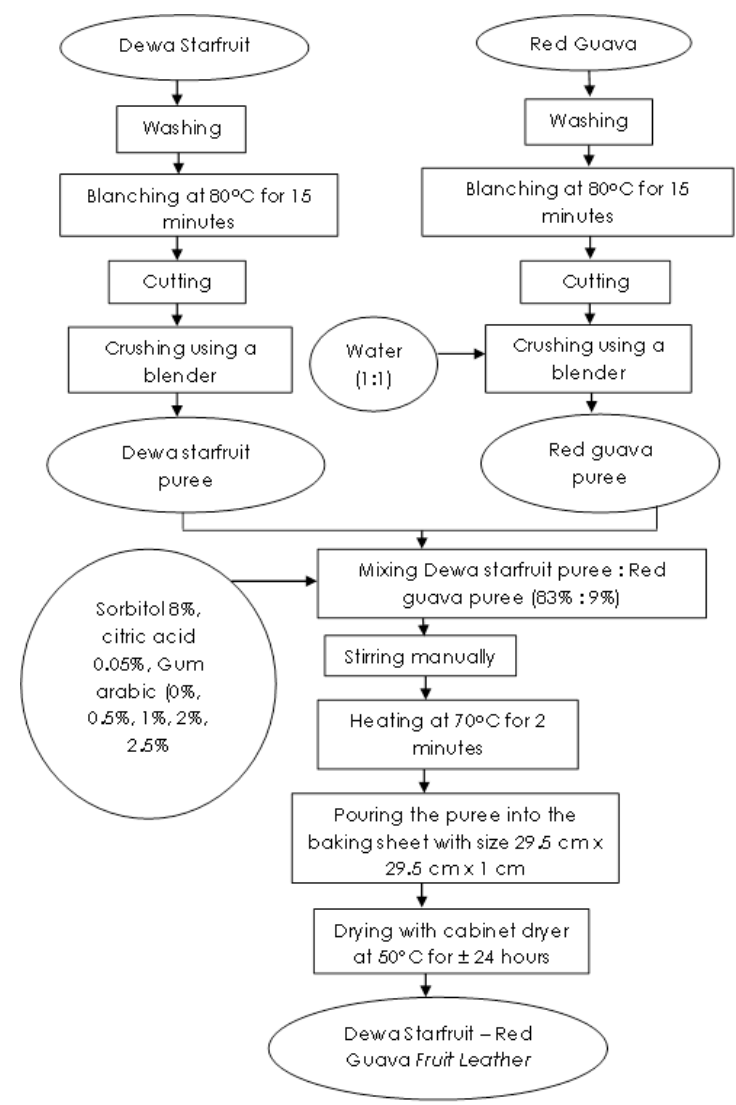

Figure 1 Production process of Dewa starfruit-red guava fruit leather (modification [1])

\subsection{Data Analysis Technique}

The resulted data were analysed using single factor analysis of variance (ANOVA) with three replications. Any significant difference of the treatments (gum arabic concentration) were followed by further Duncan's Multiple Range Tests (DMRT) at 95\% confidence level.

\subsection{RESULT AND DISCUSSION}

The characteristic observations have been made on the produced fruit leather. The results are presented in Table 1 and 2. 


\subsection{Tensile Strength Value}

The tensile strength value of the Dewa starfruit-red guava fruit leather shown in Table 1 ranged from 294.12 to $553.75 \mathrm{gf}$. The range of tensile strength is suitable for fruit leather in general. It is proven by the results of other research that the tensile strength of pineapple-carrot fruit leather ranged from 196.91 gf - 345.79 gf [20], and the tensile strength of banana fruit leather ranged from $591.81 \mathrm{gf}-667.30$ gf [1]. Table 1 showed that the tensile strength value increased with the increasing of the Arabic gum concentration. The ANOVA results showed that the addition of different Arabic gum concentrations had a significantly different effect $(p<0.05)$ on the tensile strength value of the fruit leather. Tensile strength is calculated based on the force required to stretch the fruit leather until it breaks [12].

Table 1 Physicochemical and microbiological characteristics of Dewa starfruit - red guava fruit leather

\begin{tabular}{lccccc}
\hline \multirow{2}{*}{ Quality Parameters } & \multicolumn{4}{c}{ Gum arabic concentration } \\
\cline { 2 - 6 } Tensile strength value (gf) & $\mathbf{0 \%}$ & $\mathbf{0 . 5 \%}$ & $\mathbf{1 \%}$ & $\mathbf{2 \%}$ & $\mathbf{2 . 5 \%}$ \\
\cline { 2 - 6 } Water content (\%) & $294.12 \pm 29.35^{\mathrm{a}}$ & $437.38 \pm 75.10^{\mathrm{ab}}$ & $465.60 \pm 71.82^{\mathrm{b}}$ & $467.90 \pm 93.72^{\mathrm{b}}$ & $553.75 \pm 80.27 \mathrm{~b}$ \\
Ash content (\%) & $7.63 \pm 0.44^{\mathrm{a}}$ & $7.38 \pm 0.43^{\mathrm{a}}$ & $7.62 \pm 0.29 \mathrm{a}$ & $7.17 \pm 0.22^{\mathrm{ab}}$ & $6.63 \pm 0.31^{\mathrm{b}}$ \\
Crude fiber content (\%) & $1.88 \pm 0.13^{\mathrm{a}}$ & $2.02 \pm 0.02^{\mathrm{b}}$ & $2.07 \pm 0.01^{\mathrm{bc}}$ & $2.14 \pm 0.01_{\mathrm{cd}}^{\mathrm{c}}$ & $2.18 \pm 0.01^{\mathrm{d}}$ \\
Vitamin C content (mg/lo0g) & $1.78 \pm 0.09 \mathrm{a}$ & $1.85 \pm 0.10^{\mathrm{a}}$ & $2.09 \pm 0.32^{\mathrm{a}}$ & $2.11 \pm 0.41^{\mathrm{a}}$ & $2.32 \pm 0.17 \mathrm{a}$ \\
PH content & $76.91 \pm 1.19 \mathrm{a}$ & $77.08 \pm 1.22^{\mathrm{a}}$ & $77.61 \pm 2.35^{\mathrm{a}}$ & $82.96 \pm 0.25^{\mathrm{b}}$ & $86.53 \pm 0.53^{\mathrm{c}}$ \\
Water activity content & $4.16 \pm 0.05^{\mathrm{a}}$ & $4.22 \pm 0.03^{\mathrm{ab}}$ & $4.23 \pm 0.04^{\mathrm{b}}$ & $4.25 \pm 0.02^{\mathrm{bc}}$ & $4.31 \pm 0.03^{\mathrm{c}}$ \\
Total bacteria (CFU/g) & $0.49 \pm 0.03^{\mathrm{a}}$ & $0.48 \pm 0.02^{\mathrm{a}}$ & $0.46 \pm 0.02^{\mathrm{a}}$ & $0.46 \pm 0.03^{\mathrm{a}}$ & $0.44 \pm 0.00^{\mathrm{a}}$ \\
Total yeast and mold (CFU/g) & $<2.5$ & $<2.5$ & $<2.5$ & $<2.5$ & $<2.5$ \\
\hline
\end{tabular}

Notes: Values with different superscript letters are significantly $(p<0.05)$ different

In this research, Arabic gum acts as a gelling agent. Gel formation is a process of the crosslinking of polymer chains to form a continuous three-dimensional network capable of trapping liquids, forming a rigid and sturdy texture [21]. This caused the fruit leather to be difficult to break because it required a large amount of energy to break these cross-links. Patil et al. [22] also stated that a denser fruit leather structure requires more energy to break down the fruit leather so that it can be swallowed. Thus, the higher the concentration of Arabic gum, the higher tensile strength value of the starfruit-red guava fruit leather. This is in accordance with Astuti et al. (2015) [1] where the addition of 0.3-0.9 percent gum arabic on the fruit leather of banana caused an increase in the value of tensile strength from $591.81 \mathrm{gf}-667.30 \mathrm{gf}$. The difference in the tensile strength of fruit leather may be due to the different types of fruit used. In this research, $0.5 \%$ Arabic gum produced the correct tensile strength value for starfruit-guava fruit leather. Fruit leather which has high tensile strength, has better resistance to tensile forces so that it is not easily broken and torn [23]

One of the quality characteristics of fruit leather is that it has an elastic texture. The use of hydrocolloids is important to maintain the desired texture of the fruit leather. The desired texture value is the texture value that is still accepted by sensory testing. Hydrocolloid is used as a gelling agent which is able to bind water molecules thereby increasing the texture properties of the desired food material [24]. Al-Hinai et al., [25] also studied that the hardness level of the fruit leather dates increased with increasing concentrations of hydrocolloids used (starch, pectin, dextrin, and guar gum).

\subsection{Water Content}

The water content of starfruit-red guava fruit leather shown in Table 1 was ranged from 6.63 to 7.63 percent. Table 1 showed that the water content of fruit leather relatively decreased as the Arabic gum concentration was higher. The ANOVA result showed that the addition of Arabic gum with different concentrations had significant effect ( $p<$ 0.05 ) on the water content in fruit leather.

Arabic gum is a hydrocolloid which is used as a gelling agent. The presence of a large number of hydroxyl $(-\mathrm{OH})$ groups in the hydrocolloid can increase its affinity to bind water molecules to make it a hydrophilic compound. Gel formation is the formation of cross-linked polymer chains to form a three-dimensional network that can trap water in it to form rigid structures [26]. Therefore, the amount of free water and adsorbed water in the fruit leather decreased. The higher the Arabic gum concentration made the higher the amount of water absorbed, so that the water content in the fruit leather decreased. Lower water content in the fruit leather is a favorable condition because microorganisms are difficult to live and can extend shelf life. Suna et al., (2014) [27] showed that water content of fruit leather below $15 \%$ can prevent microbial growth. Overall, the water content of the fruit leather, starfruit, red guava still meets the SNI No. 1718-1996 regarding dried candied fruit, which states that the maximum moisture content of dried candied fruit is $25 \%$ [28]. 


\subsection{Ash Content}

The ash content of the Dewa starfruit-red guava fruit leather ranged from 1.88 to 2.18 percent. Table 1 showed that the ash content of fruit leather increased as the Arabic gum concentration was higher. The ANOVA results showed that the addition of Arabic gum with different concentrations had a significant effect ( $p<0.05$ ) on the ash content of the fruit leather.

The difference in the ash content of the fruit leather is due to the presence of several minerals in gum arabic brand El-Nasr which was used in this research, namely $0.17 \%$ of calcium, $3.90 \%$ of magnesium, $0.00004 \%$ of iron, $0.0004 \%$ of sodium, and $2.07 \%$ of potassium. The ranged ash content of starfruit-guava fruit leather is similar with the ranged ash content of jackfruit leather (1.96 to 2.01 percent) with the addition of gum arabic $0-0.9 \%$ [12]. It was observed that using higher gum arabic resulted in higher ash content.

Yebeyen et al. (2009) [29] reported availability of several minerals in Arabic gum, such as calcium, magnesium, iron, sodium, phosphorus, potassium, and non detectable traces of $\mathrm{Pb}, \mathrm{Co}, \mathrm{Cu}, \mathrm{Zn}, \mathrm{Ni}$, $\mathrm{Cd}, \mathrm{Cr}$, and $\mathrm{Mn}$. The Arabic gum used in this research is Arabic gum that grows in Sudan, while the gum arabic used in Yebeyen et al. (2009) [29] grows in Ethiopia. Thus it produced a different mineral content.

\subsection{Crude Fiber Content}

The crude fiber content of the starfruit-red guava fruit leather ranged from 1.78 to 2.32 percent. Table 1 showed that the crude fiber content of the fruit leather increased as the gum arabic concentration was higher. The ANOVA results showed that the addition of different concentrations of gum arabic did not have a significant effect ( $p>0.05$ ) on the crude fiber content of the fruit leather.

The increase in crude fiber content of fruit leather was due to the presence of soluble and insoluble dietary fiber in Arabic gum. In Arabic gum used, there are $76.20 \mathrm{mg}$ of soluble dietary fiber and $13 \mathrm{mg}$ of insoluble dietary fiber in $150 \mathrm{~g}$ of gum arabic, meaning that the concentration of Arabic gum can increase fruit leather fiber content. This is in line with Nainggolan et al. (2015) [30] that the addition of 0.6-1.2 percent of Arabic gum can increase the amount of crude fiber content of pineapple-broccoli fruit leather (1.72 to 3.72 percent).

According to the Regulation of the Minister of Health of the Republic of Indonesia Number 28 of 2019, concerning the Recommended Nutritional Adequacy Rate (RDA) for the Indonesian people, the recommended amount of fiber per person per day ranges from 11-23 $\mathrm{g}$ for the age group of infants and children, 22-37 $\mathrm{g}$ for the male 10-80 years old group, and $20-32 \mathrm{~g}$ for the $10-80$ year old female age group. Starfruit-guava fruit leather as much as $2 \mathrm{~g}$ (1 roll) can meet the nutritional adequacy rate of fiber of $0.2-0.5 \%$ for the category of infants and children, $0.14-0.23 \%$ for the male age group $10-80$ years old, and $0.16-0.25 \%$ for the female age group 10-80 years old.

\subsection{Vitamin C Content}

The vitamin C content of Dewa starfruit-red guava fruit leather ranged from 76.91 to $86.53 \mathrm{mg} / 100 \mathrm{~g}$. Table 1 showed that the vitamin $\mathrm{C}$ content of fruit leather increased as the gum arabic concentration was higher. The ANOVA results showed that the addition of gum arabic with different concentrations had a significant effect ( $p<0.05$ ) on the vitamin $\mathrm{C}$ content of the fruit leather. Gum arabic is a hydrocolloid that can form a gel so that it can protect vitamin $\mathrm{C}$ from oxidative damage [31]. Silalahi et al. (2014) [32] also said that Arabic gum also has the ability to inhibit the oxidation process. Therefore, the higher the concentration of gum arabic added, the higher the levels of vitamin $C$ fruit leather. Another factor that is thought to cause increased levels vitamin $C$ of starfruit-guava fruit leather is a decrease in water content. The decrease in water content is caused by the amount of water absorbed by gum arabic, so that water-soluble vitamin $C$ is also absorbed along with the water.

According to the Regulation of the Minister of Health of the Republic of Indonesia, concerning the recommended nutritional adequacy rate (RDA) for the Indonesian people, the recommended amount of vitamin $C$ per person per day ranges from $40-45 \mathrm{mg}$ for the age group of infants and children, 50-90 $\mathrm{mg}$ for the male age group, and $50-75 \mathrm{mg}$ for the female age group [33]. Vitamin C content of Dewa starfruit-red guava fruit leather ranged from 76.91 to $86.53 \mathrm{mg} / 100 \mathrm{~g}$. So it can be stated that 1 roll of fruit leather as much as $2 \mathrm{~g}$ can met the nutritional adequate rate of vitamin $C$ as much as $4 \%$ for the category of infants and children, $2-3 \%$ for the male age group $10-80$ years old, and $2 \%$ for the female age group $10-80$ years old.

\section{$3.6 \mathrm{pH}$ Value}

The $\mathrm{pH}$ value of the fruit leather ranged from 4.164.31. Table 1 showed that the $\mathrm{pH}$ value of the fruit leather increased with increasing concentration of gum arabic. The ANOVA results showed that the addition of different Arabic gum concentrations had a significant effect $(\mathrm{p}<0.05)$ on the $\mathrm{pH}$ value of the fruit leather. Arabic gum has the ability to bind water and water has properties to bind organic acids. So that the higher the concentration of Arabic gum, the more water is bound, and organic acids are bound by water [34]. Therefore, the measured amount of free organic acid is less. A low acid concentration can be indicated by a high $\mathrm{pH}$ value.

The $\mathrm{pH}$ value of the fruit leather indicated that this fruit leather is an acid food. Acid food is defined as a food with a $\mathrm{pH}$ value of 4.60 or lower [35]. Lower $\mathrm{pH}$ in fruit leather would be advantageous because it would not be support growth of disease-causing bacteria. According to his research [36], Arabic gum dissolves at acidic 
pH. Immeson (1999) [37] states that gum arabic can reach a maximum viscosity at $\mathrm{pH}$ 3.9-4.9. This $\mathrm{pH}$ condition will help to form the colloidal properties of the fruit leather solution, so that the fruit leather sheets can be formed properly.

\subsection{Water Activity Value}

The water activity value of fruit leather ranged from 0.44 to 0.49 . Table 1 showed that the water activity value of fruit leather relatively decreased with the increased in Arabic gum concentration. The ANOVA results showed that the addition of different Arabic gum concentrations did not have a significant effect ( $p>0.05$ ) of the water activity (aw) value of the fruit leather. This is in line with Astuti et al. (2015) [1] that the addition of 0-0.9 percent of Arabic gum produces the water activity of horn plantain fruit leather which ranged from 0.54-0.56. In comparison, pineapple-carrot fruit leather has a water activity value of 0.37 at the addition of Arabic gum 0.3-0.9\% [20].

Water activity is the amount of free water in food materials that can be used for the growth of microorganisms. The decrease in the value of water activity was associated with the decrease in water content, indicating the decrease amount of free water which required for microorganism activity. Water that evaporated during the drying process is included in the free water group which is not strongly bound [38].

Water activity can predict the types of microorganisms that can live and have the potential to become a source of decay and infection. The value of water activity on the fruit leather was lower than the aw value for the growth needs of bacteria, molds and yeasts. Pathogenic microorganisms could not grow at aw $<0.86$, while molds and yeasts were more tolerant of these conditions. Wherein the mold and yeast did not grow at aw $<0.62$ [39]. The relatively small value of water activity in fruit leather products can inhibit the growth of bacteria, mold, and yeast. However, the aw value of $0.44-0.49$ in fruit leather still allowed to lipid oxidation, non-enzymatic browning, and enzyme activity.

\subsection{Total Bacteria Value}

The total bacteria value of fruit leather indicated that the bacterial growth less than $2.5 \mathrm{CFU} / \mathrm{g}$. According to the Bacteriological Analytical Manual [16], the conditions for the plates that can be counted are 25 to 250 colonies. However, based on the results shown in Table 1, the resulting bacterial colonies were less than 25 , so the data obtained could not be analyzed by ANOVA.

According to SNI 7388: 2009 [40], the maximum standard limit for microbial contamination of dried fruit sweets for total bacteria is $1 \times 10^{5}$ colonies / $\mathrm{g}$.

Based on the total results of the fruit leather bacteria, it can be stated that the total bacterial Dewa starfruit-red guava fruit leather still meets the standard of dried fruit sweets. The total value of bacteria obtained is relevant with the result of aw fruit leather value, which is less than 0.9, so that this condition can inhibit the growth of bacteria in the Dewa starfruit-red guava fruit leather product. Low water content and $\mathrm{pH}$ value can also inhibit microbial growth and extend shelf life, which further affected the health of consumers [41].

Based on this, Arabic gum has an effect in reducing the $\mathrm{pH}$ of the Dewa starfruit-red guava fruit leather, so that low pH conditions can inhibit the growth of microorganisms. This was in line with the effect of gum arabic in reducing the water content of the fruit leather, which showed the decreasing amount of free water required for microorganism activity.

\subsection{Total Yeast and Mold Value}

The total yeast and mold value of fruit leather indicates the growth of yeast and mold less than $1.0 \mathrm{CFU} / \mathrm{g}$. According to the Bacteriological Analytical Manual [17], the requirements for the plates that can be counted are 10 to 150 colonies. However, based on the results shown in Table 1, the resulting yeast and mold colonies were less than 10 , so the data obtained could not be analyzed by ANOVA.

According to SNI 7388: 2009 [40], the maximum standard limit for microbial contamination of dried fruit sweets for total yeast and mold were $5 \times 10^{1}$ colonied/g. Based on the results of the total yeast and mold, it can be stated that the total yeast and mold of Dewa starfruit-red guava fruit leather still met the standard of dried fruit sweets. The total value of yeast and mold obtained relevant with the aw value fruit leather that is produced, which is less than 0.6 will inhibit the growth of yeast and mold in the products of Dewa starfruit-red guava fruit leather. These results were expected since fruit leathers had low $\mathrm{pH}$ and Iwater content. Thus this fruit leather was expected to have a stable shelflife for several months. Similar results of microbial stability of fruit leather are also reported in guava papaya fruit leather, the growth of microorganism were also well within the safe limit for consumption till 4 months of storage period [42].

Based on the research results, Arabic gum has an effect in reducing the $\mathrm{pH}$ of the Dewa starfruitred guava fruit leather, so that low $\mathrm{pH}$ conditions can inhibit the growth of microorganisms. This is in line with the effect of gum arabic in reducing the water content of the fruit leather, which shows the decreasing amount of free water required for microorganism activity.

\subsection{Sensory Test}

The sensory test of the Dewa starfruit-red guava fruit leather includes the hedonic test and the hedonic quality for the parameters of color, aroma, texture, and flavor. The results of the fruit leather sensory test are presented in Table 2.

\subsubsection{Color}

Color, an important attribute in food products, can be assessed either by a sensory panel [43]. The score value of color on fruit leather ranged from 3.0 
to 3.5 (golden yellow - orange) with acceptance value ranged from 3.7-3.8 (like). The ANOVA results showed that the addition of gum arabic with different concentrations had a significant effect ( $\mathrm{p}$ $<0.05$ ) on the score value of color on the fruit leather.

Table 2 Sensory test of Dewa starfruit - red guava fruit leather

\begin{tabular}{|c|c|c|c|c|c|}
\hline \multirow{2}{*}{$\begin{array}{c}\text { Concentration of } \\
\text { gum arabic }\end{array}$} & \multirow[t]{2}{*}{ Parameters } & \multicolumn{4}{|c|}{ Attributes } \\
\hline & & Color & Aroma & Taste & Texture \\
\hline \multirow[t]{2}{*}{$0 \%$} & Score & $3.0 \pm 0.08 a$ & $2.5 \pm 0.08$ & $3.5 \pm 0.03$ & $3.5 \pm 0.08 a$ \\
\hline & Acceptance & $3.8 \pm 0.06$ & $3.6 \pm 0.08$ & $3.9 \pm 0.03$ & $3.6 \pm 0.03 a b$ \\
\hline \multirow[t]{2}{*}{$0.5 \%$} & Score & $3.1 \pm 0.06 a b$ & $2.7 \pm 0.05$ & $3.5 \pm 0.08$ & $3.6 \pm 0.05^{a}$ \\
\hline & Acceptance & $3.8 \pm 0.12$ & $3.6 \pm 0.10$ & $3.9 \pm 0.09$ & $3.6 \pm 0.05^{b}$ \\
\hline \multirow[t]{2}{*}{$1 \%$} & Score & $3.3 \pm 0.05^{b}$ & $2.7 \pm 0.16$ & $3.5 \pm 0.10$ & $3.7 \pm 0.03^{b}$ \\
\hline & Acceptance & $3.8 \pm 0.06$ & $3.6 \pm 0.08$ & $3.8 \pm 0.03$ & $3.8 \pm 0.05 c$ \\
\hline \multirow[t]{2}{*}{$2 \%$} & Score & $3.5 \pm 0.05^{c}$ & $2.7 \pm 0.12$ & $3.5 \pm 0.03$ & $2.6 \pm 0.10^{c}$ \\
\hline & Acceptance & $3.8 \pm 0.06$ & $3.6 \pm 0.12$ & $3.9 \pm 0.05$ & $3.7 \pm 0.03 c$ \\
\hline \multirow[t]{2}{*}{$2.5 \%$} & Score & $3.5 \pm 0.14 c$ & $2.8 \pm 0.36$ & $3.5 \pm 0.08$ & $2.7 \pm 0.08 c$ \\
\hline & Acceptance & $3.7 \pm 0.06$ & $3.6 \pm 0.08$ & $3.8 \pm 0.03$ & $3.5 \pm 0.05^{a}$ \\
\hline
\end{tabular}

Score description:

Score: Color: 1 (light yellow); 2 (yellow); 3 (golden yellow); 4 (orange); 5 (red). Starfruit Aroma: 1 (not very strong); 2 (not strong); 3 (slightly strong); 4 (strong); 5 (very strong). Starfruit Taste: 1 (not very strong); 2 (not strong); 3 (slightly strong); 4 (strong); 5 (very strong). Texture: 1 (very inelastic); 2 (not elastic); 3 (slightly elastic); 4 (elastic); 5 (very elastic)

Acceptance: 1 (very dislike); 2 (dislike); 3 (rather like); 4( (like); 5 (very like)

The yellow color of the fruit leather indicated the presence of $\beta$-cryptoxanthin which is a color pigment in starfruit [44]. While the orange color in the fruit leather is the result of a combination of yellow pigments in star fruit and red pigments in red guava. According to Pasupuleti et al. (2014) [45], red guava has carotenoid compounds, especially lycopene pigments of $6900 \mu \mathrm{g} / 100 \mathrm{~g}$ and $\beta$ carotene of $430 \mu \mathrm{g} / 100 \mathrm{~g}$ [46]. According to Guine (2015) [47], the dehydration process can change the surface characteristics of food, as well as its color and reflectance. Chemical changes in pigments such as carotene and chlorophyll are produced by heat and oxidation during drying. In general, the longer the processing time and the higher the temperature, the greater the loss of the pigment.

Fruit leather with a concentration of $0 \%$ gum arabic has a golden yellow color. In comparison, fruit leather with a concentration $2.5 \%$ gum arabic has a reddish yellow (orange) color. It was darker than the color of the fruit leather without the addition of gum arabic. This is supported by Praseptiangga et al. (2014) [12] which stated that the level of preference for panelists to the color of jackfruit fruit leather decline along with the higher concentration of gum arabic. The color change is caused by the Maillard reaction. The maillard reactions in fruit leather is possibly caused by the presence of proteins contained in Arabic gum. Apart from the protein content, gum arabic also contains monosaccharide molecules which act as reducing sugars [12].

\subsubsection{Aroma}

The value of the aroma quality assessed from the Dewa starfruit-red guava fruit leather is the intensity of the starfruit aroma. Table 2 showed that the value of the fruit leather aroma ranged from 2.5 to 2.8 (rather strong), which indicated that the scent of starfruit from the fruit leather was rather strong, with an acceptance value was 3.6 (like). The ANOVA result showed that the addition of gum arabic with different concentrations did not significant effect $(a=0.05)$ to the value of the score aroma of fruit leather.

According to Jumansyah et al. (2017) [48], gum arabic is odorless when consumed by humans, so the addition of gum arabic did not affect the aroma of fruit leather. This is reinforced by [49], that hydrocolloids do not contain volatile ingredients which can cause aroma and color to food ingredients. The value of score aroma that is assessed from the Dewa starfruit-red guava fruit leather is the intensity of the starfruit aroma. According to Pino et al. (2011) [50], there were fiftysix volatile components in starfruit identified 18.9 $\mathrm{mg} / \mathrm{kg}$ ), the main ones being butyl acetate, ethyl decanoic and hexadecanoic acid.

\subsubsection{Taste}

The value of the taste quality assessed from the Dewa starfruit-red guava fruit leather is the intensity of the starfruit taste. Table 2 showed that the value of the fruit leather taste is 3.5 (strong) which indicated that the taste of starfruit from the fruit leather was strong, with an acceptance value ranged from 3.8 to 3.9 (likes). The ANOVA results showed that the addition of gum arabic with different concentrations did not have a significant effect ( $p>0.05$ ) to the value of the score taste of fruit leather. It caused of gum arabic has no taste. so the taste produced by the Dewa starfruit-red guava fruit leather is the original taste of starfruit. Similar results of their research that the addition of gum arabic did not affect the taste of the crude albumin fish cork [51].

\subsubsection{Texture}

The value of the texture quality assessed from the The value of the score texture assessed from the Dewa starfruit-red guava fruit leather was the intensity of the fruit leather elasticity. Table 2 showed that the value of the fruit leather texture ranged from 2.6 (slightly elastic) to 3.5 (elastic), with 
a acceptance value ranged from 3.5 to 3.8 (like). The ANOVA results showed that the addition of gum arabic with different concentrations had significant effect $(p<0.05)$ to the value of the score texture of fruit leather.

Texture is an important parameter in determining the quality of the fruit leather. The texture produced by the fruit leather is influenced by the type and concentration of hydrocolloids $[52 ; 53]$. The texture parameter tested on the panelists is the level of elasticity of the fruit leather. The elasticity level of the fruit leather increased until the addition of $1 \%$ gum arabic, but decreased in the addition of $2 \%$ and $2.5 \%$ gum arabic. The decrease in the elasticity of the fruit leather possibly caused by the concentration of gum arabic that is too high.

In this research, gum arabic act as a gelling agent. Gel formation is a process of cross-linking polymer chains to form a continuous threedimensional network capable of trapping liquids, forming a rigid and sturdy texture [21]. This made the fruit leather difficult to break because it required a large amount of energy to break these cross-links. Thus the higher concentration of gum arabic, then the more water was bound by gum arabic, so that the amount of free water contained in the material decreased, as a result the fruit leather water content was lower. This caused a decrease in the level of elasticity of the fruit leather [54].

The decrease in the level of elasticity of the fruit leather was also caused by the increase in the tensile strength value along with the increasing concentration of arabic gum. This is relevant with their research [55) about the jackfruit fruit leather, which showed that the addition of gum arabic can decreased water content of the fruit leather, which caused the texture of fruit leather tight and less elastic. The addition of gum arabic with a $0.9 \%$ w/w was too high and caused the texture of the fruit leather was tough, dry texture, and difficult to chew. This statement is directly proportional to the water content of the Dewa starfruit-red guava fruit leather relative decline with the concentration of gum arabic. Siburian and Dahang [56] also stated that high water content will produce a soft texture indicated by a lower texture value. Therefore, there is optimum limit to use a Arabic gum to produce the desire texture of fruit leather.

\subsection{CONCLUSION}

The addition of gum arabic at different concentrations $10 \%, 0.5 \%, 1 \%, 2 \%$, and $2.5 \%)$ in produced fruit leather from starfruit-red guava was significantly different at $a=0.05$ on the parameters of tensile strength, water content, ash content, vitamin $\mathrm{C}$ content, $\mathrm{pH}$ value, hedonic quality value of color, hedonic value and hedonic quality value of texture. Increasing concentration of gum arabic improve the tensile strength, ash content, vitamin c content, $\mathrm{pH}$ value but decrease water content. However, there is no significant effect on crude fiber content, water activity value, hedonic value of color, hedonic value and hedonic quality value of aroma, as well as hedonic value and quality hedonic value of flavor.

Fruit leather which produces the best quality is the fruit leather with the addition of $0.5 \%$ gum arabic. In addition, 1 roll of fruit leather as much as 2 grams can meet the nutritional adequacy rate of vitamin $\mathrm{C}$ by $4 \%$ for the infant and child category, $2-3 \%$ for the male age group $10-80$ years, and $2 \%$ for the 10-80 years, and can meet the nutritional adequacy rate of fiber of $0.2-0.5 \%$ for the category of infants and children, $0.14-0.23 \%$ for the male age group $10-80$ years, and $0.16-0.25 \%$ for the 10-80 year age group for women.

\section{Acknowledgement}

This research is fully supported by PT Indofood Sukses Makmur Tbk which has provided research funding in the Indofood Riset Nugraha program based on the letter of agreement No. SKE.015 / CC / IX / 2019. The authors would like to fully thank to PT Indofood Sukses Makmur Tbk and the Sahid University for the approved funding that made this research work.

\section{References}

[1] Astuti, T., Widowati, E, dan Atmaka, W. 2015. Kajian Karakteristik Sensoris, Fisik, dan Kimia Fruit Leather Pisang Tanduk (Musa corniculata Lour) dengan Penambahan Berbagai Konsentrasi Gum Arab. Jurnal Teknologi Hasil Pertanian. 8(1): 6-14.

[2] Demarchi, S. M., Ruiz, N. A. Q., Concellon, A., and Giner, S. A. 2013. Effect of Temperature on Hot-Air Drying Rate and On Retention of Antioxidant Capacity in Apple Leathers. Food and Bioproducts Processing. 9(4): 310318. DOI: 10.1016/j.fbp.2012.11.008.

[3] Chavan, U. D., and Shaik, J. B. 2015. Standardization and Preparation of Guava Leather. International Journal of Advanced Research in Biological Sciences. 2(11): 102-113.

[4] Vasanthakaalam, H., Muhimpundu, J., Karayire, A., and Fabien, M. 2018. Stability of Vitamin C and $\beta$-Carotene During Processing of Papaya Guava Fruit Leather. Carpathian Journal of Food Science and Technology. 10(4): 104-115.

[5] https://www.depok.go.id/ikon-kota Accessed on January 252020.

[6] Winarti, S., Jariyah, and Kartini, R. A. 2015. Penambahan Sorbitol pada Fruit Leather Jambu Biji Merah untuk Memperbaiki Karakteristik dan Daya Simpan. Prosiding Seminar Agroindustri dan Lokakarya Nasional FKPT-TPI Program Studi TIP-UTM, 2-3 September 2015: A-155-A162.

[7] Waspadji, S. 1989. Diabetes Meliitus dan Serat Gizi Indonesia. Jurnal Gizi dan Pangan. 2: 45-55.

[8] Febriani, R., Kuswanto, K. R., dan Kurniawati, L. 2017. Karakteristik Selai Fungsional yang Dibuat dari Rasio Buah Naga Merah (Hylocereus polyhizus) - Jambu Biji Merah (Psidium guajava) - Nanas Madu (Ananas comosus) dengan Variasi Penambahan Gula. Jurnal Ilmiah Teknologi dan Industri Pangan UNISRI (JITIPARI). 3(2): 46-52.

[9] Siregar, M. R., Harun, N., and Yusmarini. 2014. Pemanfaatan Buah Belimbing Manis dan Buah Nanas dalam Pembuatan Permen Jelly. JOM Faperta. 3(1).

[10] Sanchez-Riano, A. M., Bermeo-Andrade, H. P., and Valenzuela-Real, C. P. 2018. Incidence of Hydrocolloid Type on Quality Parameters in Mango Leathers 
(Mangifera indica L.) Yulima Variety. Food Science and Technology. 38(1): 109-115.

DOI: https://doi.org/10.1590/fst.16917.

[11] Antu, M. Y., Hasbullah, R., and Ahmad, U. 2016. Dosis Blansir untuk Memperpanjang Umur Simpan Daging Buah Kelapa Kopyor. Jurnal Penelitian Pascapanen Pertanian. 13(2): 92-99.

[12] Praseptiangga, D., Aviany, T. P., dan Parnanto, N. H. R. 2016. Pengaruh Penambahan Gum Arab Terhadap Karakteristik Fisikokimia dan Sensoris Fruit Leather Nangka. Jurnal Teknologi Hasil Pertanian. 9(1): 71-83. DOI: https://doi.org/10.20961/jthp.v9i2.12858.

[13] Association of Official Analytical Chemists. 1995. Official Methods of Analysis of The Association of Official Agriculture Chemists. 16th Edition. Virginia (US): AOAC International.

[14] Association of Official Analytical Chemists. 2006. Official Methods of Analysis of The Association of Official Agriculture Chemists. 16th Edition. Virginia (US): AOAC International.

[15] Association of Official Analytical Chemists. 2005. Official Methods of Analysis of The Association of Official Agriculture Chemists. 16th Edition. Virginia (US): AOAC International.

[16] Susanto, A. 2009. Uji Korelasi Kadar Air, Kadar Abu, Water Activity dan Bahan Organik pada Jagung di Tingkat Petani, Pedagang Pengumpul dan Pedagang Besar. Seminar Nasional Teknologi Peternakan dan Veteriner.

[17] United States Food and Drug Administration (USFDA). 2011. BAM: Aerobic Plate Count.

[18] United States Food and Drug Administration (USFDA). 2011. BAM: Yeast, Molds, and Mycotoxins.

[19] Badan Standardisasi Nasional. 2006. SNI 01-2346-2006. Petunjuk Pengujian Orgnaleptik dan atau Sensori. Jakarta: Badan Standarisasi Nasional.

[20] Prasetyowati, D. A., Widowati, E., and Nursiwi, A. 2014. Pengaruh Penambahan Gum Arab terhadap Karakteristik Fisikokimia dan Sensoris Fruit Leather Nanas (Ananas comosus L. Merr) dan Wortel (Daucus carota). Jurnal Teknologi Pertanian. 15(2): 139-148.

[21] Fardiaz, D. 1989. Hidrokoloid. Pusat Antar Universitas Pangan dan Gizi Institut Pertanian Bogor. Jakarta.

[22] Patil, S. H., Shere, P. D., Sawate, A. R., and Mete, B. S. 2017. Effect of Hydrocolloids on Textural and Sensory Quality of Date-Mango Leather. Journal of Pharmacognosy and Phytochemistry. 6(5): 399-402.

[23] Marzelly, A. D., Yuwanti, S., and Lindriati, T. 2017. Karakteristik Fisik, Kimia, dan Sensoris Fruit Leather Pisang Ambon (Musa paradisiaca S.) dengan Penambahan Gula dan Karagenan. Jurnal Agroteknologi. 11 (02): 172185.

[24] Rascon-Diaz, M. P., Tejero, J. M., Mendoza-Garcia, P. G., Garcia, H. S., and Salgado-Cervantes M. A. 2012. Spray Drying Yogurt Incorporating Hydrocolloids: Structural Analysis, Acetaldehyde Content, Viable Bacteria, and Rheological Properties. Food Bioprocess Technology. 5: 560-567.

[25] Al-Hinai K. Z., Guizani, N., Singh, V., Rahman, M. S., and Al-Subhi, L. 2013. Instrumental Texture Profile Analysis of Date-Tamarind Fruit Leather with Different Types of Hydrocolloids. Food Science and Technology Research. 49(4): 531-538. DOI: 10.3136/fstr.19.531.

[26] Saha, D., and Bhattacharya, S. 2010. Hydrocolloids as Thickening and Gelling agents in Food: A Critical Review. Journal of Food Science and Technology. 47(6): 587-597. DOI: 10.1007/s13197-010-0162-6.

[27] Suna, S., Tamer, C. E., Inceday, B., Sinir, G. O., and Copur, O. U. 2014. Impact of Drying Methods on Physicochemical and Sensory Properties of Apricot Pestil. India J Tradition Knowl. 13(1): 47-55.

[28] Badan Standardisasi Nasional. 1996. SNI No. 1718. Syarat Mutu Manisan. Jakarta: Badan Standarisasi Nasional.

[29] Yebeyen, D., Lemenih, M., and Feleke, S. 2009. Characteristics and Quality of Gum Arabic from Naturally Grown Acacia Senegal (Linne) Willd. Trees in the Central Rift Valley of Ethiopia. Food Hydrocolloids. 23(1): 175-180. DOI: 10.1016/j.foodhyd.2007.12.008.
[30] Nainggolan, R. J., Lubis, L. M., and Lubis, Z. 2015 Pengaruh Perbandingan Nenas dengan Brokoli dan Konsentrasi Gum Arab terhadap Mutu Fruit Leather. Jurnal Rekayasa Pangan dan Pertanian. 3(1) : 83-94.

[31] Sinaga, D. S. M., Suhaidi, I., dan Ridwansyah. 2017. Pengaruh Perbandingan Nenas dengan Bit dan Konsentrasi Gum Arab terhadap Mutu Fruit Leather Nenas. Jurnal Rekayasa Pangan dan Pertanian. 5(2): 267-274.

[32] Silalahi, R. C., Suhaidi, I., and Nimbong, L. N. 2014. Pengaruh Perbandingan Sari Buah Sisak dengan Markisa dan Konsentrasi Gum Arab Terhadap Mutu Sorbet Air Kelapa. Jurnal Rekayasa Pangan dan Pertanian. 2(2): 27-28.

[33] Menteri Kesehatan. 2019. Perarturan Menteri Kesehatan No. 28 Tahun 2019. Angka Kecukupan Gizi yang Dianjurkan untuk Masyarakat Indonesia.

[34] Winarno, F. G. 2008. Kimia Pangan dan Gizi. Jakarta: PT. Gramedia Pustaka Utama.

[35] Felix Barron and Angela Fraser. 2013. Acidified Foods: Food Safety Considerations for Food Processors. In Innocenzo Muzzalupo (ed.). Food Industry. Nutrition and Packaging Sciences, Clemson University, Clemson, SC, USA. DOI: 10.5772/55161.

[36] Hutapea, C. A., Rusmarilin, H., and Nurminah, M. 2016. Pengaruh Perbandingan Zat Penstabil dan Konsentrasi Kuning Telur terhadap Reduced Fat Mayonnaise. Jurnal Rekayasa Pangan dan Pertanian. 4(3): 1-8.

[37] Immeson, A. 1999. Thickening and Gelling Agent for Food. New York: Aspen Publisher Inc.

[38] Anggraeni, A. A. 2011. Aktivitas Air dan Aktivitas Mikrobia. Jakarta.

[39] [FAO] Food and Agriculture Organization. 2003. Handling and Preservation of Fruits and Vegetables by Combined Methods for Rural Areas Chapter 3: General Considerations for Preservation of Fruits and Vegetables.

[40] Badan Standardisasi Nasional. 2006. SNI 01-7388-2009. Batas Maksimum Cemaran Mikroba. Jakarta: Badan Standarisasi Nasional.

[41] Safaei, P., Sadeghi, Z., Jahed Khaniki, G. 2019. The Assessment of Physical and Microbial Properties of Traditional Fruit Leathers in Tehran. Jundishapur J Health Sci. 11 (1): 1-5. DOI: 10.5812/jjhs.85814.

[42] Singh, L. J., Tiwari, R. B., and Ranjitha, K. 2020. Studies on Effect of Different Packaging Materials on Shelf-Life of Blended Guava-Papaya Fruit Leather. European Journal of Nutrition \& Food Safety. 12(8): 22-32. DOI: 10.9734/EJNFS/2020/v12i830258.

[43] Ozgur, M., Akpinar-bayizit, A., Ozcan, T., and Yilmazersan, L. 2011. Effect of Deydration on Several Physicochemical Properties and The Antioxidant Activity of Leeks (Allium porrum L.) Notulae Botanicae Horti Agrobotanici Cluj-Napocal. 39(1): 144-151. DOI: http://dx.doi.org/10.15835/nbha3915861.

[44] Khoo, H., Prasad, K. N., Kong, K., Jiang, Y., \& Ismail, A. 2011. Carotenoids and Their Isomers: Color Pigments in Fruits and Vegetables. Molecules. 16(2): 1710-1738. http://dx.doi.org/10.3390/ molecules 16021710. PMid:213 36241.

[45] Pasupuleti, V., Kukarni, S. E. 2014. Lycopene Fortification on the Quality Characteristics of Beverage Formulations Developed from Pink Flesh Guava (Psidium guava L.). Journal Food Science Technology. 51(12): 4126-4131. DOI: 10.1007/S13197-013-0932-z.

[46] Rodrigues-Amaya, D. B., Kimura, M., Godoy, H.T., and Amaya-Farfan, J. 2008. Updated Brazilian Database on Food Carotenoids: Factors Affecting Carotenoid Composition. Journal of Food Composition and $\begin{array}{lll}\text { Analysis. } & 21(6) \text { : } & 445-463 .\end{array}$ https://doi.org/10.1016/i.jfca.2008.04.00.

[47] Guine, R. P. F. 2015. Food Drying and Dehydration: Technology and Effect on Food Properties. Germany: LAP Lambert Academic Publishing $\mathrm{GmbH} \% \mathrm{Co}$.

[48] Jumansyah, H., Johan, V. S., dan Rahmayuni. 2017. Penambahan Gum Arab terhadap Mutu Sirup Kulit dan Buah Nanas (Ananas comosus L Merr.). JOM FAPERTA UR. 4(1): 1-15. 
[49] Glicksman. 1983. Food Hydrocolloid. Vol. II. Ed. CRC Press Inc Boca Raton, Florida.

[50] Pino, J. A., Marbot, R., and Aguero, J. 2011. Volatile Components of Starfruit (Averrhoa carambola L.). Journal of Essential Oil Research. 12(4): 429-430. DOl: https://doi.org/10.1080/10412905.2000.9699557.

[51] Sugianto, Suprayitno, E., and Budi, B. 2019. The Effect of Addition of Dextrin and Arabic Gum to The Quality of Crude Albumin Fish Cork (Ophiocephalus striatus). International Journal of Scientific and Research Publications. 9(7): 396-400.

DOI: http://dx.doi.org/10.29322/IJSRP.9.07.2019.p9153.

[52] Talay, R. dan Erdogan, U. 2019. The Effect of Hydrocolloids on Texture of Fruit Leathers. International Conference on Advanced Engineering Technologies 19-21 September 2019: 516-519.

[53] Shafi'i, S., Ahmad, N., Abidin, M. Z., Hani, N. M., dan Ismail, N. 2013. Optimization of Hydrocolloids and Maltodextrin Addition on Roselle-based Fruit Leather using Two-Level Full Factorial Design. International Journal of Bioscience, Biochemistry and Bioinformatics. 3(4): 387-391.

[54] Puspaningrum, L., Yuwono, S. S., and Martati, E. 2018 Karakteristik Fisikokimia dan Sensoris Fruit Leather Apel Manalagi (Malus Sylvestris Mill) dengan Substitusi Pisang Candi (Musa Paradisiaca). Jurnal Teknologi Pertanian. 19(3): 173-182.

[55] Rahmanto, S. A., Parnanto, N. H. R., dan Nursiwi, A. 2014. Pendugaan Umur Simpan Fruit Leather Nangka (Arrtocarpus heterophyllus) dengan Penambahan Gum Arab Menggunakan Metode Accelerated Shelf Life Tes (ASLT) Model Arrhenius. Jurnal Teknosains Pangan. 3(3) 35-45.

[56] Siburian. F., and Dahang, D. 2018. Impact Adding Tapioca to Fruit Leather Characteristics of Timun Suri (Cucumis melo L.). International Journal of Food Science and Nutrition. 3(1): 123-130. 